\title{
Glacier dynamics near the calving front of Bowdoin Glacier, northwestern Greenland
}

\author{
Shin SUGIYAMA, ${ }^{1}$ Daiki SAKAKIBARA, ${ }^{1,2}$ Shun TSUTAKI, ${ }^{1,3}$ Mihiro MARUYAMA,,${ }^{1,2}$ \\ Takanobu SAWAGAKI ${ }^{4}$
}

\author{
${ }^{1}$ Institute of Low Temperature Science, Hokkaido University, Sapporo, Japan \\ ${ }^{2}$ Graduate School of Environmental Science, Hokkaido University, Sapporo, Japan \\ ${ }^{3}$ Arctic Environment Research Center, National Institute of Polar Research, Tokyo, Japan \\ ${ }^{4}$ Faculty of Environmental Earth Science, Hokkaido University, Sapporo, Japan \\ Correspondence: Shin Sugiyama <sugishin@lowtem.hokudai.ac.jp>
}

\begin{abstract}
To better understand recent rapid recession of marine-terminating glaciers in Greenland, we performed satellite and field observations near the calving front of Bowdoin Glacier, a $\mathbf{3} \mathbf{~ k m}$ wide outlet glacier in northwestern Greenland. Satellite data revealed a clear transition to a rapidly retreating phase in $\mathbf{2 0 0 8}$ from a relatively stable glacier condition that lasted for $>\mathbf{2 0}$ years. Ice radar measurements showed that the glacier front is grounded, but very close to the floating condition. These results, in combination with the results of ocean depth soundings, suggest bed geometry in front of the glacier is the primary control on the rate and pattern of recent rapid retreat. Presumably, glacier thinning due to atmospheric and/or ocean warming triggered the initial retreat. In situ measurements showed complex short-term ice speed variations, which were correlated with air temperature, precipitation and ocean tides. Ice speed quickly responded to temperature rise and a heavy rain event, indicating rapid drainage of surface water to the bed. Semi-diurnal speed peaks coincided with low tides, suggesting the major role of the hydrostatic pressure acting on the calving face in the force balance. These observations demonstrate that the dynamics of Bowdoin Glacier are sensitive to small perturbations occurring near the calving front.
\end{abstract}

KEYWORDS: Arctic glaciology, glacier calving, glacier flow, ice/ocean interactions, subglacial processes

\section{INTRODUCTION}

The Greenland ice sheet has been losing mass at accelerating rates since the 1990s (Rignot and others, 2011; Shepherd and others, 2012). Satellite measurements and numerical modeling results have shown that the current mass loss of the Greenland ice sheet is primarily due to increased surface melt and ice discharge from accelerated marine-terminating outlet glaciers (Sasgen and others, 2012; Enderlin and others, 2014; Khan and others, 2014). The overview of the ongoing changes has been revealed by previous studies based on an increasing number of data available from satellite measurements and numerical modeling. However, field data in Greenland are temporally and spatially sparse, leaving mass budget details and related processes insufficiently understood. For example, field observations on tidewater glaciers are limited to several glaciers, so the driving mechanism of glacier acceleration is poorly constrained.

Acceleration, thinning and retreat of outlet glaciers are playing key roles in recent rapid ice loss in Greenland. Detailed observational data have been reported for several large glaciers on the southeastern and southwestern coast (e.g. Thomas and others, 2000; Joughin and others, 2004; Howat and others, 2005, 2007; Nettles and others, 2008), and a growing body of evidence has revealed widespread glacier changes over Greenland (McFadden and others, 2011; Kjær and others, 2012; Moon and others, 2012). The driving mechanism of observed changes is not well understood, but several processes are thought to be of importance. Numerical modeling results suggest that glacier and fjord bed geometry play a critical role in the frontal variations of tidewater glaciers (e.g. Nick and others, 2009). It is argued that ice discharge increases when the glacier terminus retreats into deeper water, resulting in thinning and further glacier retreat (e.g. Schoof, 2007). Change in ocean temperature is suspected to be a trigger of these rapid changes. For example, thinning and acceleration of Jakobshavn Isbræ coincided with a rise in ocean temperature in the late 1990s (Holland and others, 2008). The system is complex, as the ocean temperature is influenced by meltwater discharge from the glaciers into the ocean (e.g. Murray and others, 2010; Straneo and Heimbach, 2013).

To validate these hypotheses, it is crucial to collect detailed field data, i.e. bed geometry, ice velocity, ocean water temperature and fjord circulation, which are difficult to measure by remote-sensing techniques. Nevertheless, in situ observational data are sparse, particularly near the terminus of marine-terminating outlet glaciers. This is because the ice surface is heavily crevassed, making field activity extremely difficult. Consequently, relatively few attempts have been made to obtain high-frequency ice velocity measurements near the calving front (e.g. Amundson and others, 2010; Andersen and others, 2010; de Juan and others, 2010), resulting in limited understanding of short-term ice flow variations of tidewater glaciers in Greenland. Moreover, the fjord in front of a calving glacier is often filled with icebergs and sea ice, which makes ocean measurements logistically challenging. For this reason, ocean bathymetry proximal to the glacier terminus is often unknown, so it is difficult to interpret the rapid changes in frontal position and ice velocity near the calving front.

To investigate the processes occurring near the calving front of a tidewater glacier, we carried out field and satellite 

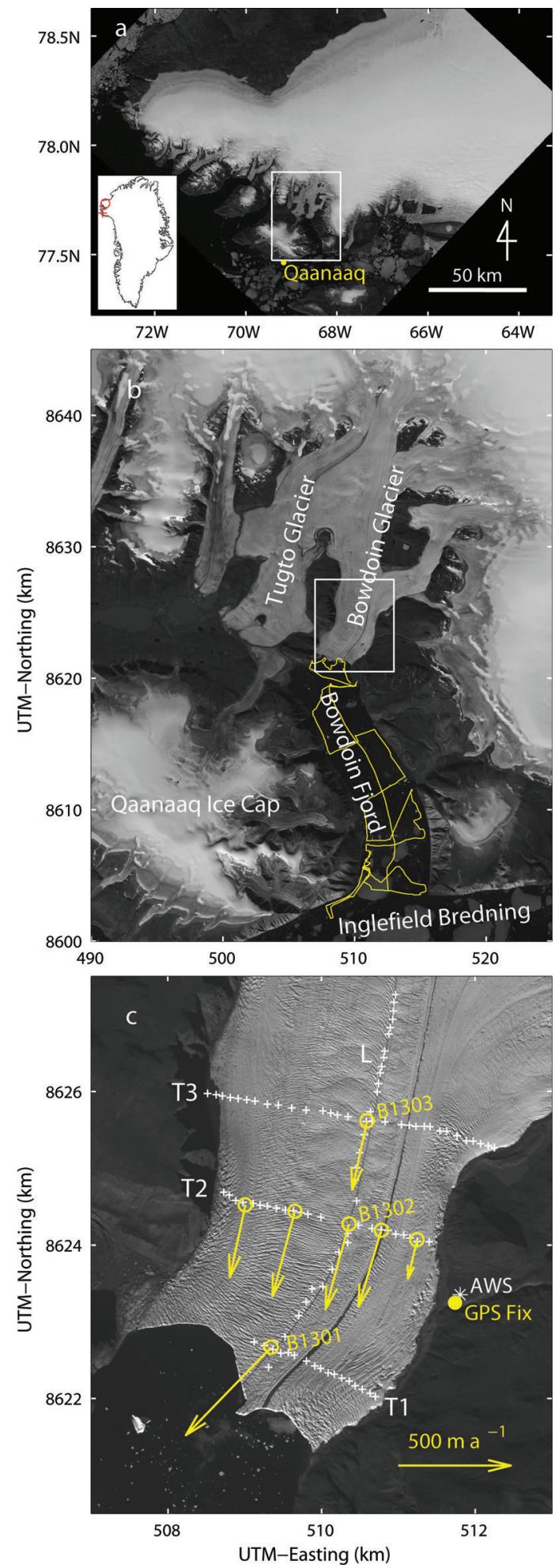

Fig. 1. (a) Satellite image (Landsat, 5 February 1999) showing northwestern Greenland including the region studied. The box indicates the area shown in (b). The inset shows the location of the region in Greenland (circle), and the temperature and tidal measurement site at Pituffik/Thule (cross). (b) Landsat image of Bowdoin Glacier and Bowdoin Fjord. Ocean depth survey routes are indicated by yellow lines. White box indicates the area covered by (c). (c) Satellite image (ALOS (Japanese Advanced Land Observing System) PRISM (Panchromatic Remote-sensing Instrument for Stereo Mapping), 25 July 2010) of the study site, showing the locations of the measurement sites for ice radar (crosses), ice velocity (empty circles), the GPS reference station (filled circle) and the automatic weather station (AWS; asterisk). The ice radar profiles are labeled $\mathrm{L}$ and $\mathrm{T} 1-\mathrm{T} 3$. The arrows are horizontal surface flow vectors from 13 to 26 July 2013 (from 13 to 21 July only for B1301). observations on Bowdoin Glacier, northwestern Greenland (Fig. 1). This glacier was selected because of its recent rapid retreat, proximity to Qaanaaq Airport and relatively safe ice surface condition near the calving front. The study is part of a research project focused on the ice mass budget in northwestern Greenland and processes driving recent mass loss in this region (e.g. precipitation trends, surface albedo, ice speed and sub-marine melting). The research area includes marine-terminating outlet glaciers, ice caps and the marginal part of the ice sheet near Qaanaaq, one of the northernmost villages in Greenland. Relatively few observations exist in northern Greenland, compared to the south. Recent studies showed acceleration and retreat of glaciers in northwestern Greenland (McFadden and others, 2011; Kjær and others, 2012; Carr and others, 2013; Khan and others, 2013), consistent with recently accelerating mass loss in this area (Khan and others, 2010). These observations suggest that ice mass loss is spreading from the south to the northwest, so collecting data in this region is of crucial importance. Following the previous report on field measurements on Qaanaaq Ice Cap (Sugiyama and others, 2014), this paper reports field and satellite data obtained at Bowdoin Glacier.

\section{STUDY SITE}

Bowdoin Glacier $\left(77^{\circ} 41^{\prime} \mathrm{N}, 68^{\circ} 35^{\prime} \mathrm{W}\right)$ is a marine-terminating outlet glacier located $30 \mathrm{~km}$ northeast of Qaanaaq in northwestern Greenland (Fig. 1). It forms part of an outlet glacier system in the Greenland ice sheet with the adjacent land-terminating Tugto Glacier (Fig. 1b). A $20 \mathrm{~km}$ long fastflowing feature initiates at $\sim 800 \mathrm{~m}$ a.s.l., and branches into Bowdoin and Tugto Glaciers at $10 \mathrm{~km}$ from the terminus. Ice surface near the glacier front is covered by crevasses, as commonly observed on fast-flowing calving glaciers. However, the glacier surface is accessible on foot, with the exception of the heavily crevassed western half of the nearterminus region. This access enabled us to perform detailed measurements. The glacier discharges into Bowdoin Fjord through a $3 \mathrm{~km}$ wide calving front. At $20 \mathrm{~km}$ south of the calving front, Bowdoin Fjord connects to the largest fjord in this region, Inglefield Bredning. Several glaciers flow into Inglefield Bredning and they have retreated over recent decades (Porter and others, 2014). Measurements in the nearby ocean showed the existence of relatively warm Atlantic Water below $150 \mathrm{~m}$ depth, suggesting its importance in glacier changes in this region (Porter and others, 2014).

In July 2013 and July 2014, we carried out field measurements on the lower $5 \mathrm{~km}$ of Bowdoin Glacier and performed a bathymetric survey in Bowdoin Fjord (Fig. 1b and c). In addition to these field activities, we analyzed satellite data to investigate recent variations in calving front positions and the ice velocity field near the glacier front.

\section{METHODS}

\subsection{Terminus variations}

To investigate the recent frontal variations of Bowdoin Glacier, we analyzed 44 satellite images acquired in MaySeptember between 1987 and 2013. These images were acquired by the Landsat 5 Thematic Mapper (TM) sensor, the Landsat 7 Enhanced Thematic Mapper Plus (ETM+) sensor and Landsat 8 Operational Land Imager (OLI) and were distributed by the United States Geological Survey (http://landsat.usgs.gov/). We used a false-color composite 
of bands 3-5 for Landsat 5/7 and bands 4-6 for Landsat 8 . Spatial resolution of the images was $30 \mathrm{~m}$. The glacier calving front in each image was manually delineated, using geographic information software (QGIS). Changes since 1987 in the surface area near the ice front were divided by the width of the calving front to obtain the mean retreat/ advance distance. Specifically, we measured the area of a polygon formed by the calving front, parallel lines extending up-glacier from the ice front side margins and an arbitrary upstream reference line (Moon and Joughin, 2008). The accuracy of the front mapping was equivalent to the image resolution $(30 \mathrm{~m})$. The co-registration error in the repeated images used in this study was $\pm 62 \mathrm{~m}$, based on the horizontal displacement of off-ice surface features.

\subsection{Ice thickness and surface elevation}

Ice thickness was measured in the field on 7-11 July 2013 and 20 July 2014, along the central flowline (L) and along three transverse profiles (T1-T3) as shown in Figure 1c. Measurements were performed at 97 locations along the $\sim 14 \mathrm{~km}$ long survey route, approximately every 100-200 m with some irregularities due to ice surface conditions. For instance, the western half of profile T1 was not surveyed because of the aforementioned heavily crevassed surface conditions (Fig. 1c). We used an ice-penetrating radar system with a central wave frequency of $5 \mathrm{MHz}$ manufactured by The Ohio State University, Columbus, OH, USA (Fukuda and others, 2011). The expected vertical resolution for ice thickness measurements with this frequency is $8.4 \mathrm{~m}$. We placed a transmitter and receiver $20 \mathrm{~m}$ apart along the survey routes, and stretched antenna cables perpendicular to the routes. Ice thickness was computed from two-way travel times of bed-reflected radar signals, by taking a wave propagation speed proposed for solid ice $\left(168 \mathrm{~m} \mathrm{\mu s}^{-1}\right.$ ) (Glen and Paren, 1975).

At each of the radar measurement sites, the ice surface elevation was surveyed using a kinematic GPS positioning technique. We used dual-frequency GPS receivers as a rover station (Leica System 1200) and a reference station (GNSS Technology Inc., GEM-1) installed on the eastern flank of the glacier (Fig. 1c). Sea surface elevation was also measured by GPS to correct the vertical coordinate to the elevation above sea level. The GPS data were post-processed with Leica Geo Office software and have an accuracy of several centimeters in the horizontal direction, and $<10 \mathrm{~cm}$ in the vertical direction. Glacier bed elevation was then computed by subtracting the ice thickness from the surface elevation.

\subsection{Ocean depth}

Ocean depth was measured in Bowdoin Fjord on 24 and 26 July 2013 along a $\sim 90 \mathrm{~km}$ long survey route (Fig. 1b). A boat equipped with an ultrasonic echo sounder (Lowrance HDS-5 Gen2) operated with a $50 \mathrm{kHz}$ transducer (HSTDFSBL) was used. Accuracy of the depth measurement was estimated by comparing the sounder data with those obtained by a depth sensor lowered to the bed with a string. According to the calibration measurements at five locations with depths ranging from 344 to $558 \mathrm{~m}$, the rootmean-square $(\mathrm{rms})$ deviation between the sounder and the depth sensor data was $6.3 \mathrm{~m}$. The boat speed was $10 \mathrm{~km} \mathrm{~h}^{-1}$, and we sampled water depth and horizontal coordinates every second. The coordinates were obtained with a GPS mounted on the echo sounder based on a single pointpositioning technique. This on-board GPS is convenient for post-processing because depth and coordinate data are synchronized when they are recorded. Errors in the GPS single positioning are typically expected to be several meters in the horizontal direction.

\subsection{Ice flow}

\section{Satellite data analysis}

The ice velocity field of Bowdoin Glacier was measured using an image-matching method applied to the Landsat 5 TM, Landsat 7 ETM+ and Landsat 8 OLI image pairs. We employed the orientation correlation method in the frequency domain (Haug and others, 2010; Heid and Kääb, 2012) to track the displacement of glacier surface features. We used 815 pairs out of 162 images of the Landsat 5, 7 and 8 images acquired between 28 September 1987 and 1 October 2014, with temporal separations of 16-498 days. We selected images depending on the cloud coverage $(<50 \%)$ and image quality, and used image pairs which showed sufficiently good correlations when they were processed. Displacement vectors obtained from all the image pairs were weighted for temporal separations and averaged over a year, so that the result represents the annual mean ice velocity field. From this dataset, we computed annual mean ice speed at B1301, one of our in situ flow measurement sites (Fig. 1c). Errors in the velocity measurement consisted of (1) ambiguities in the cross-correlation peak, (2) co-registration errors and (3) false correlations. Errors due to (1) and (2) were estimated from the rms horizontal displacement of off-ice areas, where displacement should be zero. Errors caused by (3) were minimized by applying directional and median low-pass filters to the obtained displacement vectors (Heid and Kääb, 2012). Our error estimate for the annual mean ice speed at B1301 is 7$40 \mathrm{~m} \mathrm{a}^{-1}$, depending on image quality, temporal separation and the number of image pairs available each year.

\section{Field measurement}

Ice flow speed was also measured in the field by surveying aluminum poles installed at seven locations on the glacier (Fig. 1c). Repeated surveys were performed on 13 and 26 July 2013, except for those at B1301 made on 13 and 21 July. We used dual-frequency GPS receivers (GNSS Technology Inc., GEM-1) to obtain three-dimensional coordinates with a static positioning technique. The antenna of the GPS was mounted on top of the poles to record L1 and L2 GPS signals every second for $\sim 30 \mathrm{~min}$. GPS data were processed with those recorded at the aforementioned reference station on the eastern flank of the glacier. Coordinates were computed with GPS processing software RTKLIB (http://www.rtklib.com/rtklib.htm). With the relatively short $(<\sim 3 \mathrm{~km})$ baseline length, positioning error in the static GPS measurement is typically several millimeters in the horizontal direction. The aluminum poles were drilled into ice $>1 \mathrm{~m}$ deep to avoid the influence of wind on the measurement accuracy. Tilting of the poles due to ice melt did not occur, as they were frozen immediately after the installation. Thus, survey uncertainty was negligibly small compared to the horizontal ice motion expected at the survey sites during the measurement period.

In addition to the repeated measurements, automatic GPS receivers continuously surveyed three of the poles (B1301B1303). The GEM-1 receivers were kept running with a rechargeable battery and a solar panel to record GPS signals every second. We processed the GPS data with those from 

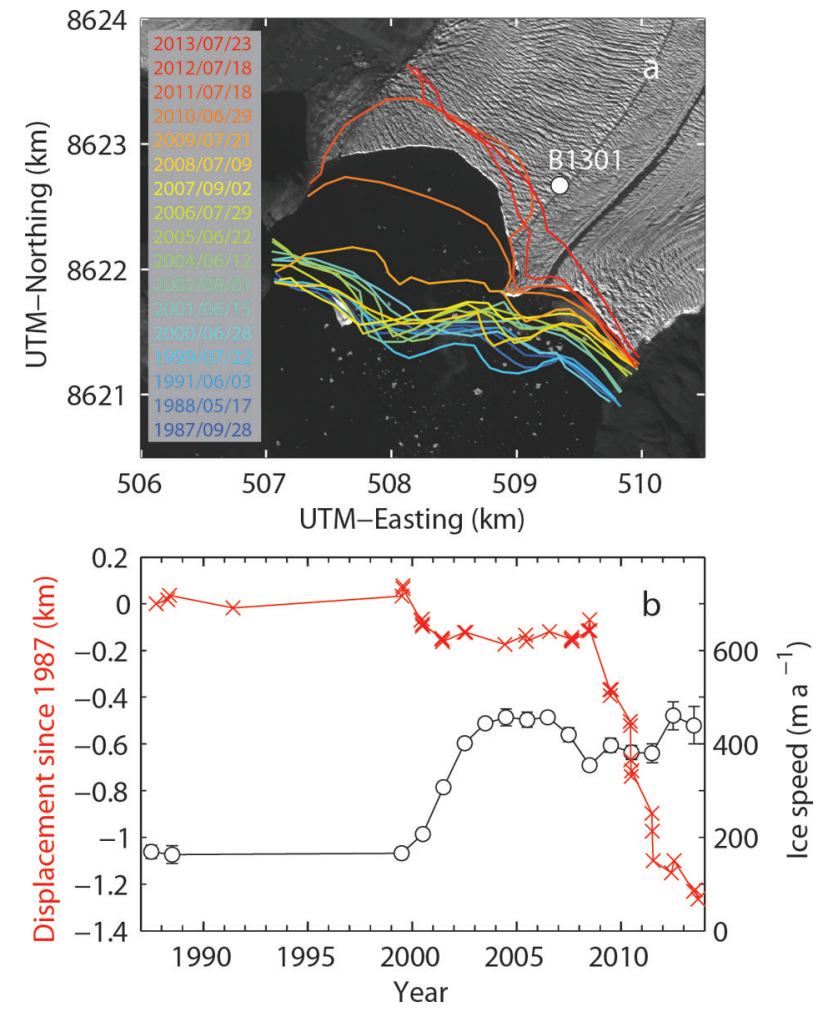

Fig. 2. (a) Frontal margins of Bowdoin Glacier observed from 28 September 1987 to 23 July 2013. Background is an ALOS PRISM image acquired on 25 July 2010. (b) The crosses are mean displacement of the glacier front since 28 September 1987. Negative change in the ordinate represents glacier retreat. The open circles are satellite-derived annual mean ice speed at site B1301 as indicated by the filled circle in (a).

the reference station using the RTKLIB software in static mode to obtain coordinates for every 15 min time window. The uncertainty of the static GPS positioning in the horizontal direction (several millimeters) is roughly equal to $10-30 \%$ of the ice motion in the $15 \mathrm{~min}$ time window. Error in the vertical direction was $\sim 5 \mathrm{~mm}$, according to previous measurements under similar conditions (Sugiyama and others, 2010). Horizontal ice speed was computed by filtering a time series of the positioning data using a Gaussian smoothing routine with a time window of 1 hour.

\subsection{Meteorological and ocean data}

Air temperature and precipitation were measured from 6 to 26 July 2013 on the eastern flank of the glacier at $100 \mathrm{~m}$ a.s.I. (Fig. 1c). We installed an automatic weather station (AWS) (Vaisala WXT520) at $1.5 \mathrm{~m}$ above the ground and recorded the data every 5 min with a data logger (Campbell Scientific, CR1000). We also used air temperature records at Pituffik/ Thule Air Base, $125 \mathrm{~km}$ south of Bowdoin Glacier (76 $53^{\prime} \mathrm{N}$, $68^{\circ} 75^{\prime} \mathrm{W}$; $59 \mathrm{~m}$ a.s.I.) (Fig. $\left.1 \mathrm{a}\right)$, to compute annual values of the positive degree-day sum (PDD). Daily mean temperatures at this station, from 1951 to 2014, are distributed by the United States National Climatic Data Center (http://www. ncdc.noaa.gov/). During our field measurement period in 2013, the correlation coefficient and the rms deviation between hourly temperature at Bowdoin Glacier and Pituffik/ Thule Air Base were 0.60 and $2.7^{\circ} \mathrm{C}$, respectively.

Tidal data in the region studied are available at Pituffik/ Thule $\left(76^{\circ} 33^{\prime} \mathrm{N}, 68^{\circ} 52^{\prime} \mathrm{W}\right)$. Sea surface level is measured by the Technical University of Denmark, Lyngby, and hourly data are provided as a part of the Global Sea Level Observing System network (http://www.gloss-sealevel.org). Sea-surface temperature (SST) near the glacier was analyzed from 1988 to 2009, using $4 \mathrm{~km}$ resolution monthly time series of Advanced Very High Resolution Radiometer (AVHRR) Pathfinder Level 3 SST data provided by the Physical Oceanography Distributed Active Archive Center (http://podaac.jpl.nasa.gov). July-August mean SST was averaged within the area $77-78^{\circ} \mathrm{N}, 66-72^{\circ} \mathrm{W}$ to compare it with the glacier front variations. Data in July-August were used because sea ice in Inglefield Bredning breaks up typically in June. We also utilized images of Moderate Resolution Imaging Spectroradiometer (MODIS) Level 1 (250 $\mathrm{m}$ resolution) to analyze the timing of summer sea-ice opening in Bowdoin Fjord. For each summer from 2000 to 2013, the initial and final dates of sea-ice coverage transitions from $100 \%$ to $0 \%$ were determined by visual inspection of MODIS images provided by NASA.

\section{RESULTS}

\subsection{Terminus variations}

The results of the satellite data analysis show rapid recent retreat of Bowdoin Glacier (Fig. 2). The terminus position had been fairly stable from 1987 to 2008 , except for a 230 m retreat from 1999 to 2001. Rapid retreat then began between July 2008 and June 2009. The retreat rate decreased in 2011, but increased again in 2012. The mean retreat distance from July 2008 to September 2013 was $1.15 \mathrm{~km}\left(0.22 \mathrm{~km} \mathrm{a}^{-1}\right)$. No clear seasonal variations are observed in our data. The magnitude of the retreat was not uniform across the glacier (Fig. 2a). From 2008 to 2013, the ice front has retreated by $2 \mathrm{~km}$ at the western margin, whereas the displacement at the eastern margin was $<0.5 \mathrm{~km}$.

\subsection{Ice thickness and bed geometry}

Ice thickness along the central flowline was 269-400 m (Fig. 3a). The glacier surface is nearly uniformly inclined at $\sim 1.6^{\circ}$, whereas the bed is relatively flat within an elevation range from -251 to $-185 \mathrm{~m}$ a.s.l. Accordingly, ice thickness gradually increases up-glacier and reaches $400 \pm 10 \mathrm{~m}$ at $5.3 \mathrm{~km}$ from the terminus. The transverse cross sections show typical glacier valley shapes, with a relatively flat bed in the glacier center and steeply inclined side-walls (Fig. 3bd). The bed geometries are asymmetric along profiles T2 and T3, indicating the valley is deeper in the western half of the glacier (Fig. 3c and d).

The measured ice thickness and bed geometry demonstrate that a large portion of ice was situated below sea level. Near the glacier center along the lowermost profile T1 (shaded region in Fig. 3b), ice below sea level was 230$253 \mathrm{~m}$ thick, equivalent to $86-89 \%$ of the entire ice thickness (264-284 m). This fraction decreases up-glacier, but $72-74 \%$ and $59-66 \%$ of full ice thickness were below sea level in the central part of the T2 and T3 profiles (shaded regions in Fig. 3c and d), respectively.

\subsection{Ocean bed geometry}

Figure 4a shows the bed elevation along the survey routes in Bowdoin Fjord and Bowdoin Glacier. In front of the glacier center, the ocean depth ranges from 190 to $210 \mathrm{~m}$ within $2 \mathrm{~km}$ of the terminus. The ocean bed deepens towards the mouth of the fjord, where the bed elevation is $<-500 \mathrm{~m}$ a.s.l. 

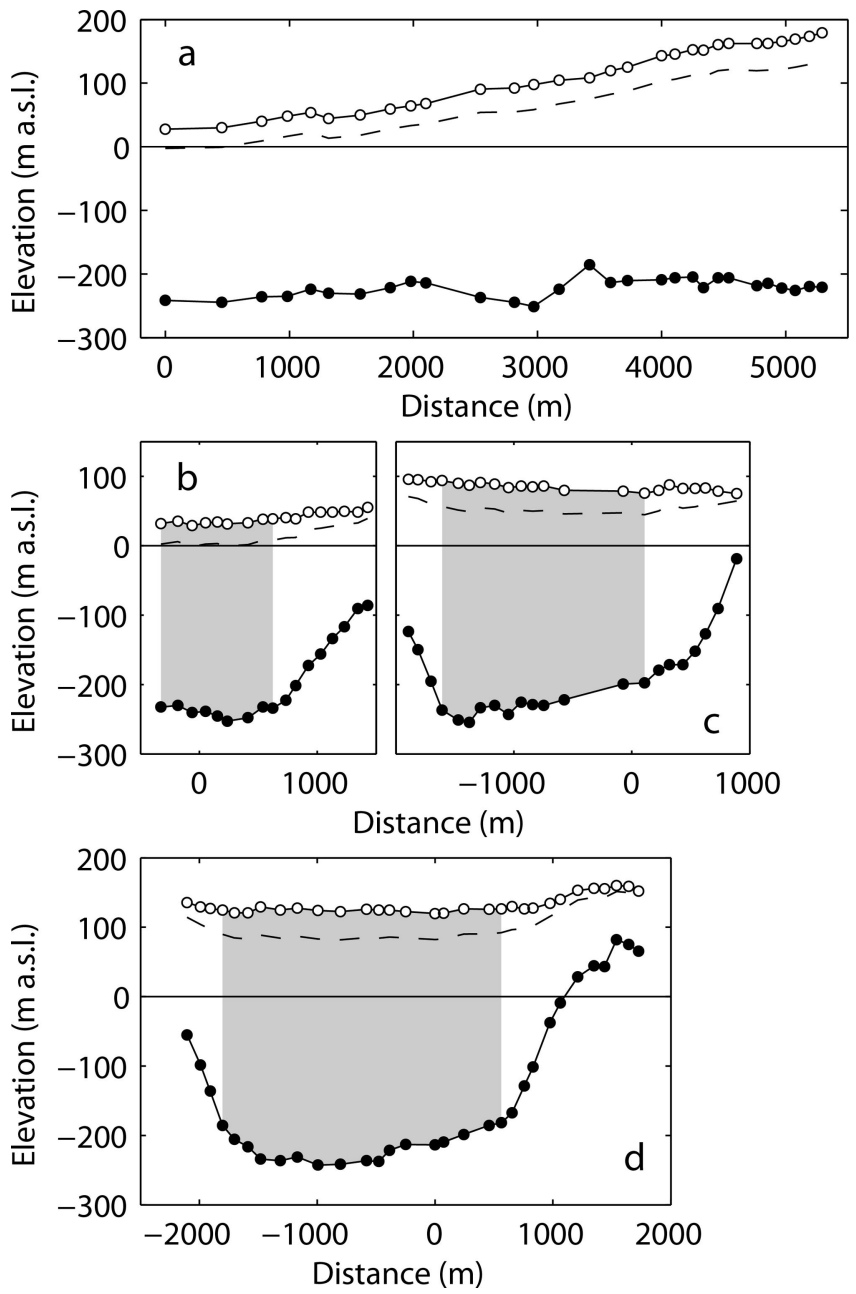

Fig. 3. Ice surface and bed elevations along the ice radar profiles shown in Figure 1c: (a) profile L, (b) profile T1, (c) profile T2 and (d) profile T3. The dashed lines are the ice flotation levels computed with ice and sea-water densities of 910 and $1025 \mathrm{~kg} \mathrm{~m}^{-3}$. The shaded regions are used to compute the fraction of ice thickness below sea level.

The greatest depth along the surveyed routes was nearly $800 \mathrm{~m}$ measured in Inglefield Bredning $1.5 \mathrm{~km}$ south of the coast (indicated by $X$ in Fig. 4a). The ocean bed elevation shows sills and steps along the center line of the fjord (Fig. 4b). Bed beneath the glacier terminus is inclined upglacier and a $\sim 50 \mathrm{~m}$ high bump was observed within a few kilometers of the calving front. From the bump, the bed deepens offshore and drops by $\sim 200 \mathrm{~m}$ at $8 \mathrm{~km}$ from the glacier front. The bed is gently inclined up the fjord between 12 and $18 \mathrm{~km}$ from the glacier, forming a sill near the mouth of the fjord.

\subsection{Ice speed}

Satellite data analysis

The mean velocity field obtained for 2013 by the satellite data shows a fast-flowing feature near the calving front (Fig. 5). Ice speed increases down-glacier and reaches a maximum value of $440 \mathrm{~m} \mathrm{a}^{-1}$ near the calving front. The ice speed averaged along the calving front is $330 \mathrm{ma}^{-1}$. In general, ice flows faster in the western half of the glacier. The relatively fast flow generates strong lateral shearing between the glacier center and western margin. Consequently, the ice surface in this region was heavily crevassed (Fig. 1c) and field activity was not possible.
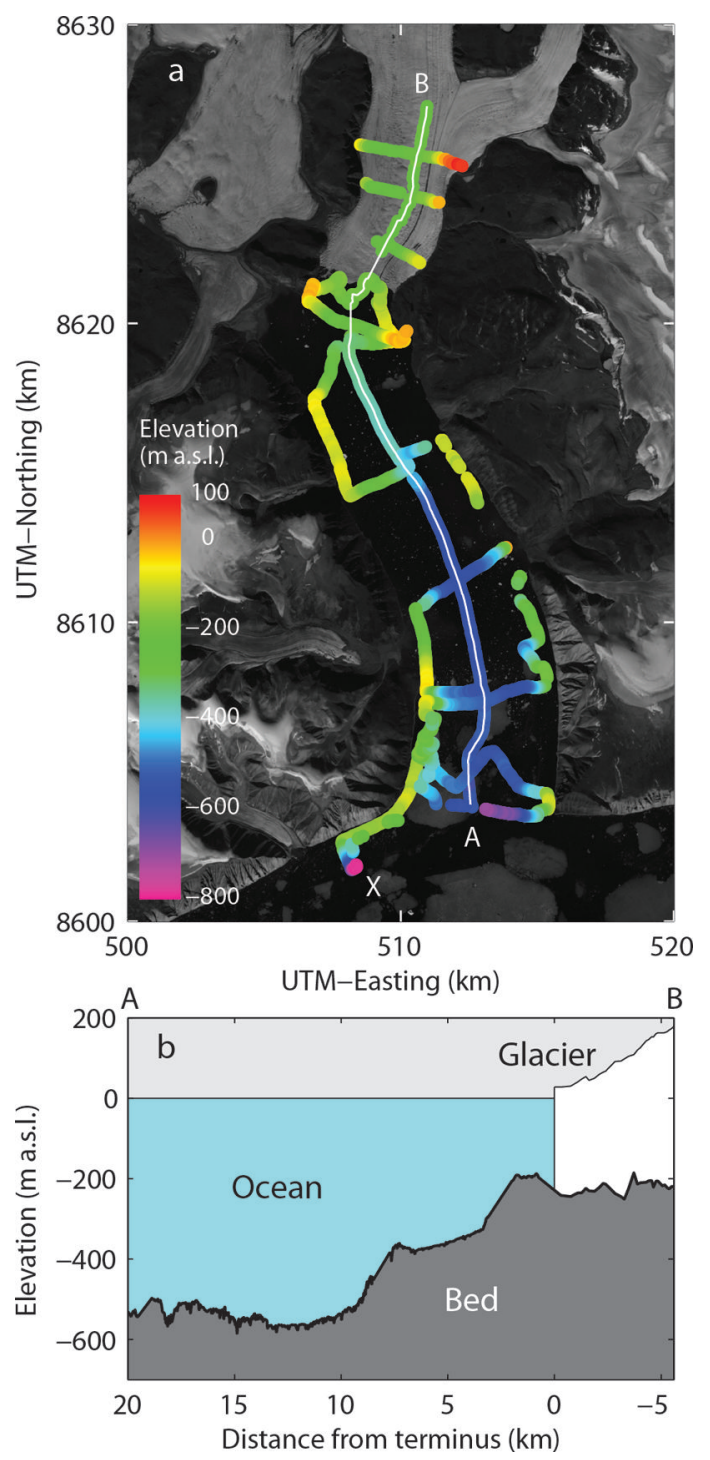

Fig. 4. (a) Ocean and glacier bed elevation along the survey routes. The location of the deepest bed along the survey routes is indicated by $X$. (b) Vertical cross section along the white curve (A-B) indicated in (a). The ocean bed, glacier bed and glacier surface elevations are based on the measurements in this study. The ice front position is as of summer 2013.

The retreat events in 1999 and 2008 were accompanied by flow acceleration. Ice speed at B1301 increased when the glacier retreated between 1999 and 2001, and reached a peak of $450-460 \mathrm{~m} \mathrm{a}^{-1}$ in 2004-06, several years after the ice front position was stabilized in 2001 (Fig. 2b). The glacier decelerated between 2006 and 2008, but accelerated again during the period of rapid retreat after 2008, when ice speed increased from $354 \pm 11 \mathrm{~m} \mathrm{a}^{-1}$ in 2008 to $460 \pm 30 \mathrm{~m} \mathrm{a}^{-1}$ in 2012 .

\section{Field measurement}

Along the glacier center line at B1301, B1302 and B1303, mean ice speeds over the survey period were 544, 391 and $313 \mathrm{~m} \mathrm{a}^{-1}$, respectively (Fig. 1c). The speed increases towards the calving front, indicating a stretching flow regime with a longitudinal strain rate of $6-8 \times 10^{-2} \mathrm{a}^{-1}$. Along the transverse stake profile, ice flows relatively faster in the western half of the glacier (Fig. 1c), which is consistent with the velocity field obtained by the satellite analysis (Fig. 5) as well as the greater ice thickness observed 


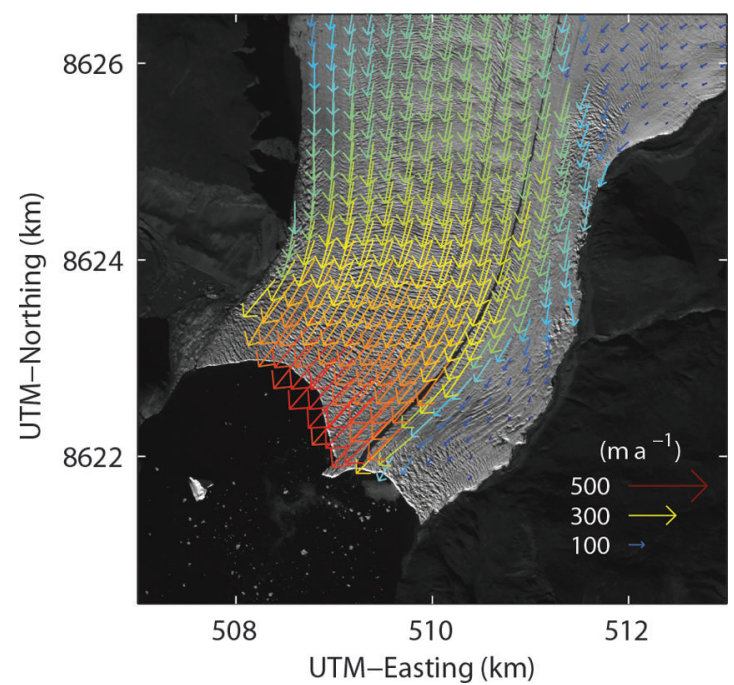

Fig. 5. Surface ice velocity field of Bowdoin Glacier. The velocity vectors were measured by 58 satellite images taken from 2 June 2012 to 1 October 2014 and averaged for the year 2013. Background is an ALOS PRISM image acquired on 25 July 2010.

in this region (Fig. 3c and d). These speeds observed in July are up to $30 \%$ greater than the annual mean values measured by the satellite data. As the mean of the seven GPS sites, our data showed $18 \%$ acceleration (relative to the annual mean) during the field measurement period (13-26 July 2013).
The continuous GPS measurements revealed complex ice speed variations (Fig. 6a). The highest frequency of the variations is semi-diurnal, as clearly observed at B1301. These variations were associated with the tides. Also observed are diurnal variations with faster flow in the evening. The fastest ice flow during the period occurred on 13 July at all the GPS sites, which coincided with a heavy rain event. Overall, speed gradually increases from the beginning of the measurement, and then decreases after the speed-up event on 13 July. Speed-up was also observed on 18 and 26 July, when relatively high air temperature was recorded. Overall features of the velocity variations are similar at stakes B1301-B1303 (Fig. 6a).

The vertical ice motion was downward in the studied region (Fig. 6b). Mean rates of the vertical displacement were $-3.7,-12.0$ and $-11.9 \mathrm{~m} \mathrm{a}^{-1}$ at stakes B1301, B1302 and $\mathrm{B} 1303$, respectively. When these trends are subtracted from the elevation data, detrended displacements indicate relatively upward ice surface motion until the speed-up event on 13 July (Fig. 6b). The motion was relatively downward after the event and then turned upward again at around 23 July. No clear correlation was observed between the vertical ice motion and tide.

\section{DISCUSSION}

\subsection{Glacier and fjord geometry}

Our radar measurements revealed that the glacier ice was deeply submerged below sea level (Fig. 3). Along the central flowline, ice below sea level accounts for $60-90 \%$ of the full
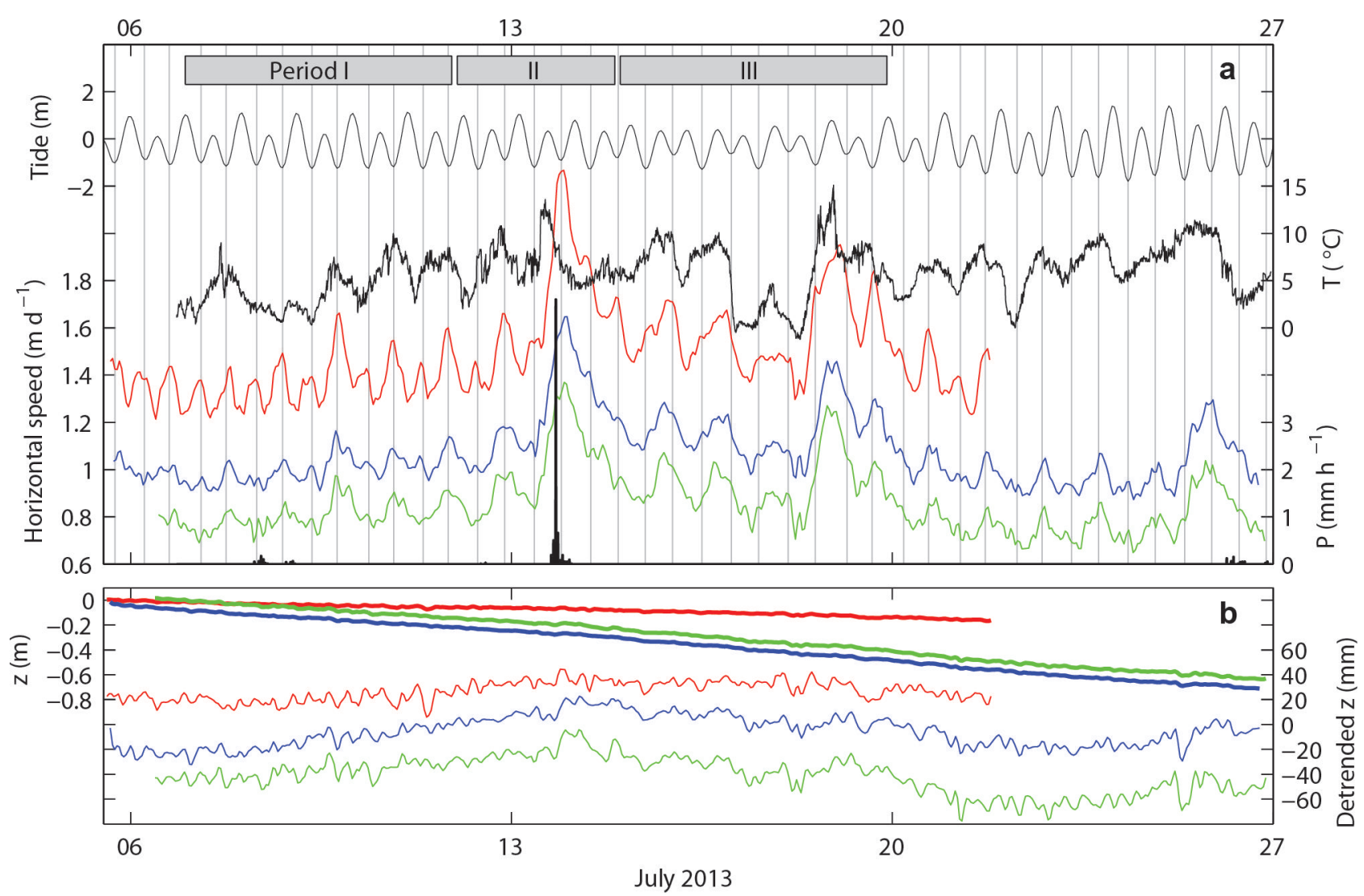

Fig. 6. (a) Ice speed measured at B1301 (red), B1302 (blue) and B1303 (green). Also indicated are ocean tide at Pituffik/Thule (thin black), air temperature (black) and hourly precipitation measured by the AWS. The vertical grey lines show the time of the low tide. Details of periods I-III are shown in Figure 8. (b) Thick lines are vertical ice surface motion at B1301 (red), B1302 (blue) and B1303 (green). Thin lines are the same data, but trends over the measurement period are removed. 
ice thickness (Fig. 3a). Sea level at the glacier front is nearly equal to the ice flotation level, suggesting that the glacier terminus is grounded (Fig. $3 a$ and b). The lack of tidal vertical ice motion also indicates a grounded condition (Fig. 6b). Nevertheless, sea level was very close to the flotation level, suggesting that calving triggered by ice flotation regulates ice front position. This hypothesis is consistent with the previously proposed idea that the front position is controlled by the ice thickness above flotation and rapid retreat of a calving glacier is initiated by thinning of ice (Van der Veen, 1996). Near the calving front, ice progressively thins as it flows down-glacier under the influences of stretching ice flow and surface melting. Presumably, calving occurs when ice becomes thinner than the threshold and sea level reaches the flotation level.

The results of the ocean depth and ice thickness measurements suggest that bed geometry plays a key role in the recent retreat of Bowdoin Glacier. In front of the glacier, the ocean bed slopes up-glacier from the bump at $1-2 \mathrm{~km}$ from the calving front (Fig. 4b). The glacier front rapidly retreated over this region from 2008 to 2013 (Fig. 2a). Tidewater glaciers are thought to be unstable when the ice front locates on an up-glacier sloping bed (e.g. Schoof, 2007; Nick and others, 2009). Observations in other regions in Greenland also confirm rapid recession of tidewater glaciers which are underlain by overdeepened beds (e.g. Howat and others, 2007; Thomas and others, 2009). Thus, it is likely that the initial retreat in 2008 caused detachment of the glacier front from the bump, triggering the subsequent rapid retreat. The retreat pattern across the terminus can also be attributed to the basal topography. The terminus retreated more rapidly in the western half of the glacier because the deepest trough is located off-center as indicated by the ice radar data (Fig. 3c and d).

We suggest the importance of bed geometry in the observed rapid retreat, but we also suspect climatic and/or oceanic forcings as a trigger. Both records of the PDD at Pituffik/Thule Air Base and the SST over the nearby ocean show warming since the late 1990s (Fig. 7). The smaller but marked retreat in 1999-2001 corresponds to this transition to warming. The PDD and SST rose further after 2005, suggesting an increase in surface and frontal ablation prior to the retreat initiated in 2008. From 2005 to 2012, sea ice in Bowdoin Fjord opened earlier in summer compared to the prior period (Fig. 7b). This observation is consistent with the PDD and SST trends and might have influenced the glacier dynamics as reported in previous studies in Greenland (e.g. Amundson and others, 2010). Based on these data, we hypothesize that the recent warming trends in the atmosphere and/or ocean increased the surface and/or frontal ablation, and subsequent ice thinning caused the detachment of the glacier front from the bed bump observed in front of the current terminus.

A possible impact of increasing amount of meltwater on a tidewater glacier is calving due to hydrofracture of waterfilled crevasses (Van der Veen, 1998). It is hypothesized that calving rate increases when a greater amount of meltwater is produced at the glacier surface and crevasses are filled with the meltwater. Nevertheless, most of the crevasses near the calving front were water-free during our observation period, so no evidence was obtained for the link between waterfilled crevasses and calving.

Our data showed that the retreat of Bowdoin Glacier in 1999 and 2008 was associated with ice speed increase

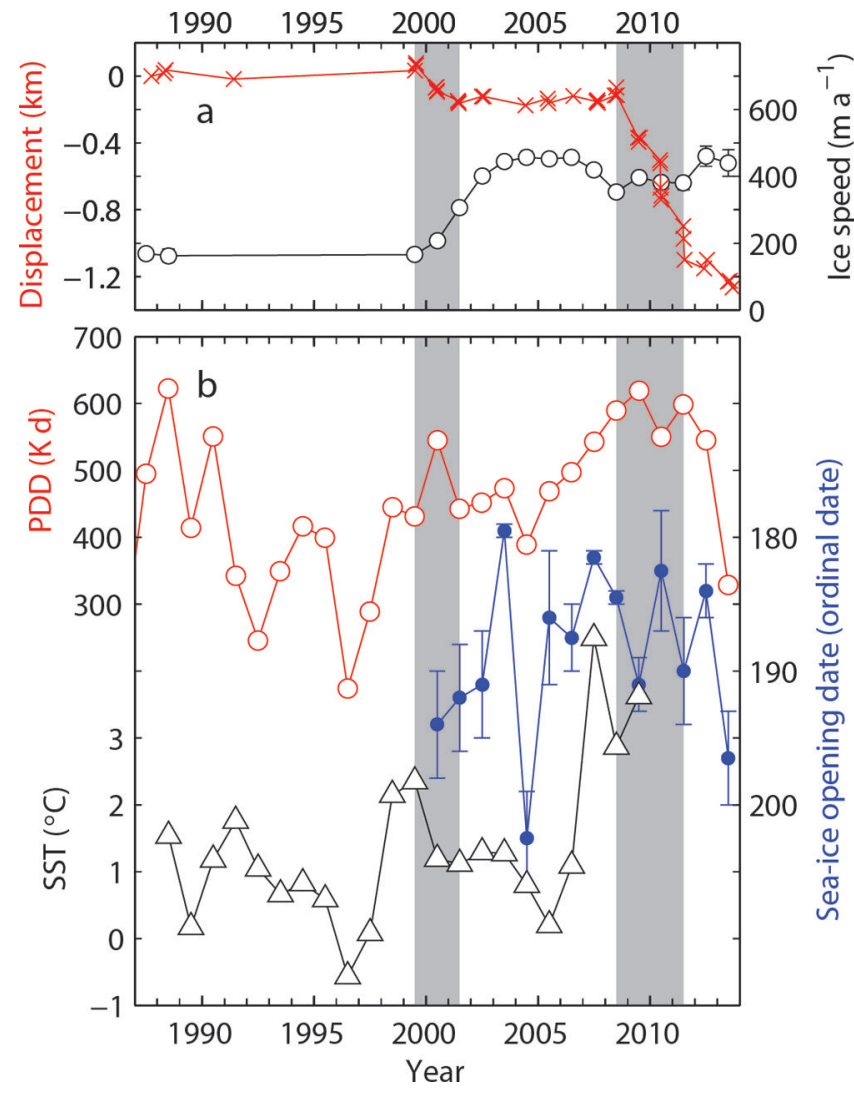

Fig. 7. (a) Mean displacement of the Bowdoin Glacier front position relative to 28 September 1987 (crosses), and annual mean ice speed at B1301 (empty circles) (see Figs 1c and 2a for the site location). (b) Annual PDD (empty circles) at Thule Air Base, July and August mean SST at $77-78^{\circ} \mathrm{N}, 66-72^{\circ} \mathrm{W}$ (triangles) and seaice opening date in Bowdoin Fjord (filled circles). The sea-ice opening date is defined as the midpoint of the transition from $100 \%$ to $0 \%$ sea-ice cover, indicated by the vertical ranges associated with the data points.

(Fig. 2b). This observation confirms a link between acceleration and rapid retreat of a calving glacier as previously reported for other outlet glaciers in Greenland (e.g. Joughin and others, 2004; Howat and others, 2005, 2007; Murray and others, 2010; Khan and others, 2013). It is likely that initial thinning and/or retreat of the glacier altered the force balance near the terminus, which resulted in the observed increase in the ice speed. The acceleration then led to further thinning and retreat of the glacier, by increasing ice discharge into the ocean.

\subsection{Short-term ice speed variations}

Ice speed was strongly modulated by tides, air temperature and precipitation (Fig. 6), indicating that the dynamics of Bowdoin Glacier are susceptible to external forcing. Tidally controlled ice speed variations have been reported on ice streams and glaciers in Antarctica (Anandakrishnan and others, 2003; Gudmundsson, 2006; Murray and others, 2007), but little is known about these variations for outlet glaciers in Greenland. From 7 to 12 July (period I), the semidiurnal ice-speed peaks at B1301 closely correspond to the low tides, which occurred in the morning from 06:00 to 08:00 and in the evening from 18:00 to 20:00 (Fig. 8a). This implies that hydrostatic pressure acting on the calving face plays a key role in speed variations. The relationship between the speed and tide differs from the observations at 

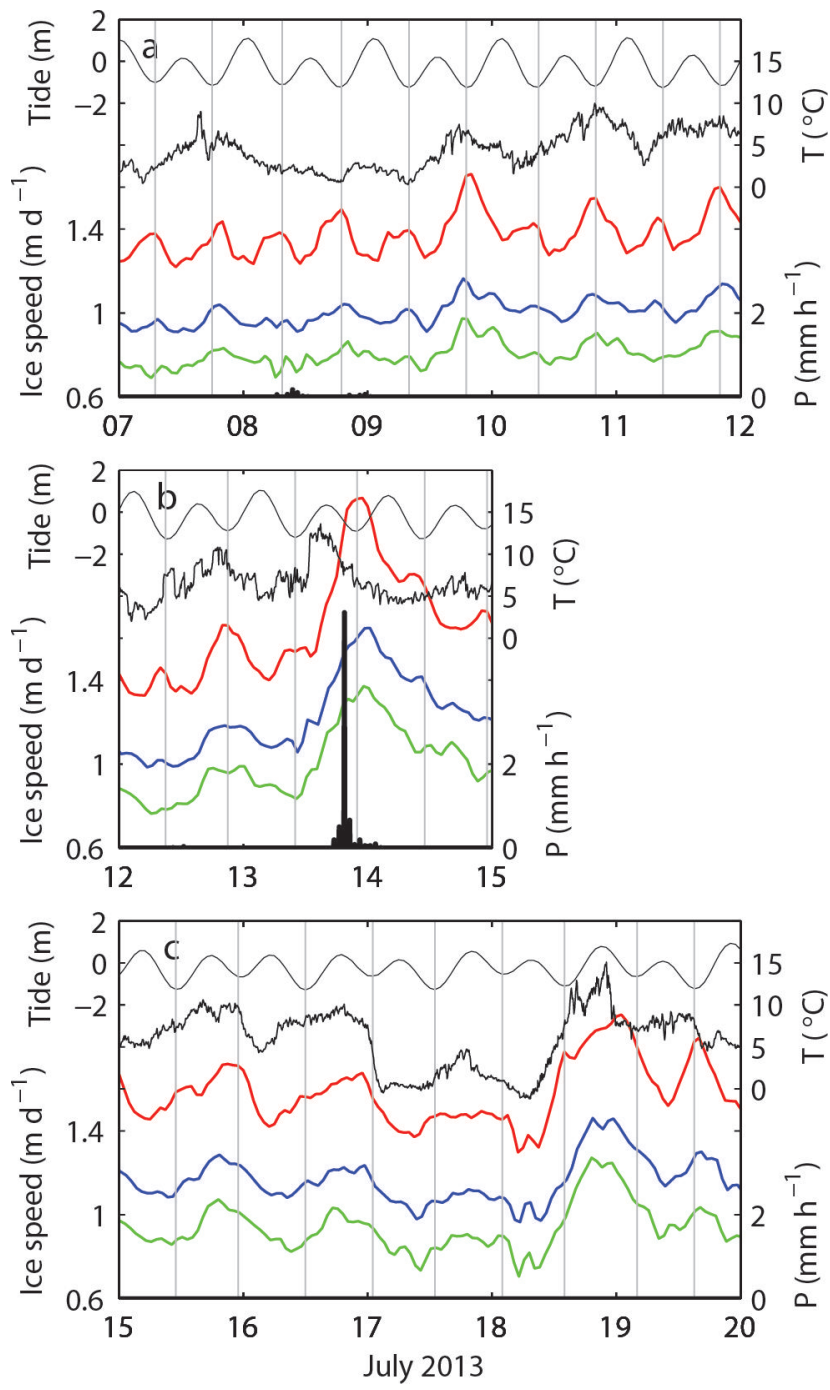

Fig. 8. Details of the ice speed measured at B1301 (red), B1302 (blue) and B1303 (green) for (a) period I (7-12 July), (b) period II (12-15 July) and (c) period III (15-20 July). Also indicated are ocean tide at Pituffik/Thule (thin black), air temperature (black) and hourly precipitation measured by the AWS. The vertical grey lines show the time of the low tide.

the grounding line of Bindschadler Ice Stream, Antarctica, where fastest ice flow occurs during the falling tide (Anandakrishnan and others, 2003). Another difference from the observations in Antarctica is the distance up-glacier to which tidal influence extends. The amplitude of the semidiurnal speed variations rapidly decreases within several kilometers of the calving front in Bowdoin Glacier, whereas tidal influence was clearly observed over several tens of kilometers from the grounding line in Antarctica (Anandakrishnan and others, 2003; Gudmundsson, 2006; Murray and others, 2007). These differences may be attributed to the fact that the Antarctic ice streams and glaciers have large floating ice, whereas Bowdoin Glacier is grounded. In Greenland, semi-diurnal speed variations were observed near the calving front of Helheim Glacier (de Juan and others, 2010). The timing of the fastest ice motion was more variable than our data, and speed peaks tended to occur slightly before low tide.

The magnitude of the evening speed-up was generally greater than that in the morning (Fig. 8a). Moreover, the speed peaks in the morning were unclear in the upper reaches at B1302 and B1303. These observations suggest that the diurnal variations (fast flow in the evening) are superimposed on the semi-diurnal signals. Most likely, ice accelerated in the evening under the influence of meltwater input to the glacier bed as frequently observed in alpine glaciers (e.g. Iken and Bindschadler, 1986). Ice is expected to be predominantly cold because annual mean air temperature at Qaanaaq is $\sim-8^{\circ} \mathrm{C}$ (Sugiyama and others, 2014). However, our data indicate that meltwater routed to the bed within several hours. We assume that the tidal influence on the ice speed decreases up-glacier, making the semi-diurnal variations unclear at B1302 and B1303.

The speed-up event on 13 July further demonstrates the response of glacier dynamics on water input to the bed. After heavy precipitation lasting for an hour from 19:00 to 20:00, ice speed peaked $\sim 2$ hours later at B1301, and 4 hours later at B1302 and B1303 (Fig. 8b). These lags can be attributed to the time required for water drainage to the glacier bed, by which we assume that basal water pressure was elevated. The earlier response at B1301 is probably due to the influence of the low tide recorded at 22:00. Ice near the front accelerated upon this low tide, which resulted in the earlier and broader speed peak observed at B1301.

From 15 to 20 July (period III), ice speed was highly correlated to temperature change (Fig. 8c), suggesting a relationship between ice speed and surface melt rate. This was observed at all three GPS sites. During this period, the correlation coefficients between hourly speed at GPS1-3 and temperature were $0.75,0.77$ and 0.75 , respectively. In addition to the diurnal variations mentioned above, ice speed was also influenced by daily temperature variations. Temperature gradually decreased from 15 to 17 July, followed by a sudden increase on 18 July. Ice speed showed similar daily variations. Assuming a hydraulic connection between the ocean and glacier bed, the lower part of Bowdoin Glacier is exposed to high basal water pressure, i.e. low effective pressure at the bed. When the basal pressure is close to the overburden pressure, small changes in basal water pressure can drive relatively large fluctuations in ice speed as reported in a temperate freshwater calving glacier in Patagonia (Sugiyama and others, 2011). Ice speed was well correlated with temperature, particularly in period III. During this period, the magnitude of low tide observed in the morning was smaller than those in the other periods. This probably resulted in less tidal influence on speed variation, and thus basal lubrication played a relatively more important role.

\subsection{Vertical ice surface motion}

Elevated basal water pressure and its influence on glacier dynamics were also suggested by the vertical ice motion. The vertical displacement relative to the mean downward motion was generally correlated with ice speed (Fig. 6). The peak elevation was observed on 13-14 July, which coincided with the transition from a generally accelerating trend until 13 July and deceleration afterwards. Upward motion was also observed later in the study period, when ice speed was elevated on 19-20 and 25-26 July (Fig. 6). A likely interpretation of the relatively upward motion during the fast flow is basal separation caused by elevated basal water pressure (e.g. Iken and others, 1983; Andrews and others, 2014). Surface uplift can be caused by ice thickening due to vertical strain (Hooke and others, 1989; Sugiyama and Gudmundsson, 2003). Nevertheless, the magnitude of the speed increase was 
greater near the terminus, which should have resulted in more tensile longitudinal strain rate and enhanced ice thinning during the period of acceleration. Thus, the uplift during the fast-flow period cannot be attributed to vertical strain. We assume that vertical surface motion of Bowdoin Glacier was controlled by basal separation, as is often hypothesized to be the case in alpine glaciers.

\section{CONCLUSION}

In order to better understand the processes driving recent rapid changes in marine-terminating outlet glaciers in Greenland, we carried out satellite and field measurements near the calving front of Bowdoin Glacier and the fjord in front of the glacier. Ice thickness and flow speed were measured in the lower $5 \mathrm{~km}$ of the glacier, and ocean depth was surveyed in a $20 \mathrm{~km}$ long fjord in front of the glacier.

Satellite data analysis showed a relatively stable glacier front position from 1987 to 2008 ( $\sim 0.1 \mathrm{~km}$ retreat), followed by a rapid retreat of $>1 \mathrm{~km}$ from 2008 to 2013. This retreat agrees with recent atmospheric and ocean surface warming trends in the region. Nevertheless, further interpretation is required with regard to the sudden transition to a rapidly retreating phase in 2008 .

The observed glacier and ocean bed geometry revealed the details of geometrical structure near the glacier front. Near the calving front, ice thickness in the central part of the glacier was $264-284 \mathrm{~m}$ and $86-89 \%$ of the ice was below sea level. Thus, the glacier front was grounded, but near the floating condition. The ice thickens and the glacier bed is elevated up-glacier, but still $59-66 \%$ of the ice was below sea level in the uppermost region of the study area. The ocean bed inclines up-glacier within several kilometers of the glacier front. Since tidewater glaciers are thought to be unstable over a reverse sloping bed, the bed geometry is able to explain the rapid retreat of Bowdoin Glacier since 2008.

Continuous ice speed measurements showed clear and complex short-term variations, which were correlated with air temperature, precipitation and ocean tides. We assume that melt- and rainwater rapidly drained to the bed through predominantly cold ice, resulting in acceleration due to enhanced basal sliding. Semi-diurnal speed variations were observed in the vicinity of the calving front. Fast flow coincided with low tide, implying that the glacier force balance is sensitive to small perturbations to the hydrostatic pressure on the calving face. These observations demonstrate the susceptibility of tidewater glacier dynamics to small external forcing.

\section{ACKNOWLEDGEMENTS}

We thank the members of the 2013 and 2014 field campaigns in Qaanaaq. Special thanks are due to Saki Daorana for providing logistic support in Qaanaaq, and to Toku Oshima for operating a boat for the ocean measurements. The manuscript was handled by the Scientific Editor Martyn Tranter, and its quality was improved by careful comments from two anonymous reviewers. This research was funded by MEXT (Japanese Ministry of Education, Culture, Sports, Science and Technology) through the Green Network of Excellence (GRENE) Arctic Climate Change Research Project. We thank $\mathrm{H}$. Enomoto for his contribution as the leader of the research project.

\section{REFERENCES}

Amundson JM, Fahnestock M, Truffer M, Brown J, Lüthi MP and Motyka RJ (2010) Ice mélange dynamics and implications for terminus stability, Jakobshavn Isbræ, Greenland. J. Geophys. Res., 115(F1), F01005 (doi: 10.1029/2009JF001405)

Anandakrishnan S, Voigt DE, Alley RB and King MA (2003) Ice Stream $\mathrm{D}$ flow speed is strongly modulated by the tide beneath the Ross Ice Shelf. Geophys. Res. Lett., 30(7), 1361 (doi: 10.1029/2002GL016329)

Andersen ML and 14 others (2010) Spatial and temporal melt variability at Helheim Glacier, East Greenland, and its effect on ice dynamics. J. Geophys. Res., 115(F4), F04041 (doi: 10.1029/ 2010JF001760)

Andrews LC and 7 others (2014) Direct observations of evolving subglacial drainage beneath the Greenland Ice Sheet. Nature, 514(7520), 80-83 (doi: 10.1038/nature13796)

Carr JR, Vieli A and Stokes C (2013) Influence of sea ice decline, atmospheric warming, and glacier width on marine-terminating outlet glacier behavior in northwest Greenland at seasonal to interannual timescales. J. Geophys. Res., 118(F3), 1210-1226 (doi: 10.1002/jgrf.20088)

De Juan J and 12 others (2010) Sudden increase in tidal response linked to calving and acceleration at a large Greenland outlet glacier. Geophys. Res. Lett., 37(12), L12501 (doi: 10.1029/ 2010GL043289)

Enderlin EM, Howat IM, Jeong S, Noh M-J, Van Angelen JH and Van den Broeke MR (2014) An improved mass budget for the Greenland ice sheet. Geophys. Res. Lett., 41(3), 866-872 (doi: 10.1002/2013GL059010)

Fukuda T, Sugiyama S, Matoba S and Shiraiwa T (2011) Glacier flow measurement and radio-echo sounding at Aurora Peak, Alaska, in 2008. Ann. Glaciol., 52(58), 138-142 (doi: 10.3189/ 172756411797252130)

Glen JW and Paren JG (1975) The electrical properties of snow and ice. J. Glaciol., 15(73), 15-38

Gudmundsson $\mathrm{GH}$ (2006) Fortnightly variations in the flow velocity of Rutford Ice Stream, West Antarctica. Nature, 444(7122), 1063-1064 (doi: 10.1038/nature05430)

Haug T, Kääb A and Skvarca P (2010) Monitoring ice shelf velocities from repeat MODIS and Landsat data - a method study on the Larsen C ice shelf, Antarctic Peninsula, and 10 other ice shelves around Antarctica. Cryosphere, 4(2), 161-178 (doi: 10.5194/tc-4-161-2010)

Heid T and Kääb A (2012) Evaluation of existing image matching methods for deriving glacier surface displacements globally from optical satellite imagery. Remote Sens. Environ., 118, 339-355 (doi: 10.1016/j.rse.2011.11.024)

Holland DM, Thomas RH, de Young B, Ribergaard MH and Lyberth B (2008) Acceleration of Jakobshavn Isbræ triggered by warm subsurface ocean waters. Nature Geosci., 1(10), 659-664 (doi: 10.1038/ngeo316)

Hooke RLeB, Calla P, Holmlund $P$, Nilsson $M$ and Stroeven A (1989) A 3 year record of seasonal variations in surface velocity, Storglaciären, Sweden. J. Glaciol., 35(120), 235-247

Howat IM, Joughin I, Tulaczyk S and Gogineni S (2005) Rapid retreat and acceleration of Helheim Glacier, East Greenland. Geophys. Res. Lett., 32(22), L22502 (doi: 10.1029/ 2005GL024737)

Howat IM, Joughin IR and Scambos TA (2007) Rapid changes in ice discharge from Greenland outlet glaciers. Science, 315(5818), 1559-1561 (doi: 10.1126/science.1138478)

Iken A and Bindschadler RA (1986) Combined measurements of subglacial water pressure and surface velocity of Findelengletscher, Switzerland: conclusions about drainage system and sliding mechanism. J. Glaciol., 32(110), 101-119

Iken A, Röthlisberger H, Flotron A and Haeberli W (1983) The uplift of Unteraargletscher at the beginning of the melt season - a consequence of water storage at the bed? J. Glaciol., 29(101), 28-47 
Joughin I, Abdalati W and Fahnestock MA (2004) Large fluctuations in speed on Greenland's Jakobshavn Isbræ glacier. Nature, 432(7017), 608-610 (doi: 10.1038/nature03130)

Khan SA, Wahr J, Bevis M, Velicogna I and Kendrick E (2010) Spread of ice mass loss into northwest Greenland observed by GRACE and GPS. Geophys. Res. Lett., 37(6), L06501 (doi: 10.1029/2010GL042460)

Khan SA and 13 others (2013) Recurring dynamically induced thinning during 1985 to 2010 on Upernavik Isstrøm, West Greenland. J. Geophys. Res., 118(F1), 111-121 (doi: 10.1029/ 2012JF002481)

Khan SA and 12 others (2014) Sustained mass loss of the northeast Greenland ice sheet triggered by regional warming. Nature Climate Change, 4(4), 292-299 (doi: 10.1038/ nclimate2161)

Kjær KH and 13 others (2012) Aerial photographs reveal late-20thcentury dynamic ice loss in northwestern Greenland. Science, 337(6094), 569-573 (doi: 10.1126/science.1220614)

McFadden EM, Howat IM, Joughin I, Smith BE and Ahn Y (2011) Changes in the dynamics of marine terminating outlet glaciers in west Greenland (2000-2009). J. Geophys. Res., 116(F2), F02022 (doi: 10.1029/2010JF001757)

Moon T and Joughin I (2008) Changes in ice front position on Greenland's outlet glaciers from 1992 to 2007. J. Geophys. Res., 113(F2), F02022 (doi: 10.1029/2007JF000927)

Moon T, Joughin I, Smith B and Howat I (2012) 21st-century evolution of Greenland outlet glacier velocities. Science, 336(6081), 576-578 (doi: 10.1126/science.1219985)

Murray T, Smith AM, King MA and Weedon GP (2007) Ice flow modulated by tides at up to annual periods at Rutford Ice Stream, West Antarctica. Geophys. Res. Lett., 34(18), L18503 (doi: 10.1029/2007GL031207)

Murray T and 10 others (2010) Ocean regulation hypothesis for glacier dynamics in southeast Greenland and implications for ice sheet mass changes. J. Geophys. Res., 115(F3), F03026 (doi: 10.1029/2009JF001522)

Nettles M and 12 others (2008) Step-wise changes in glacier flow speed coincide with calving and glacial earthquakes at Helheim Glacier, Greenland. Geophys. Res. Lett., 35(24), L24503 (doi: 10.1029/2008GL036127)

Nick FM, Vieli A, Howat IM and Joughin I (2009) Large-scale changes in Greenland outlet glacier dynamics triggered at the terminus. Nature Geosci., 2(2), 110-114 (doi: 10.1038/ ngeo394)
Porter DF and 6 others (2014) Bathymetric control of tidewater glacier mass loss in northwest Greenland. Earth Planet. Sci. Lett., 401, 40-46 (doi: 10.1016/j.epsl.2014.05.058)

Rignot E, Velicogna I, Van den Broeke MR, Monaghan A and Lenaerts J (2011) Acceleration of the contribution of the Greenland and Antarctic ice sheets to sea level rise. Geophys. Res. Lett., 38(5), L05503 (doi: 10.1029/2011GL046583)

Sasgen I and 8 others (2012) Timing and origin of recent regional ice-mass loss in Greenland. Earth Planet. Sci. Lett., 333-334, 293-303 (doi: 10.1016/j.epsl.2012.03.033)

Schoof C (2007) Ice sheet grounding line dynamics: steady states, stability, and hysteresis. J. Geophys. Res., 112(F3), F03S28 (doi: 10.1029/2006JF000664)

Shepherd A and 46 others (2012) A reconciled estimate of ice-sheet mass balance. Science, 338(6111), 1183-1189 (doi: 10.1126/ science.1228102)

Straneo F and Heimbach P (2013) North Atlantic warming and the retreat of Greenland's outlet glaciers. Nature, 504(7478), 36-43 (doi: 10.1038/nature12854)

Sugiyama S and Gudmundsson GH (2003) Diurnal variations in vertical strain observed in a temperate valley glacier. Geophys. Res. Lett., 30(2), 1090 (doi: 10.1029/2002GL016160)

Sugiyama S, Bauder A, Riesen P and Funk M (2010) Surface ice motion deviating toward the margins during speed-up events at Gornergletscher, Switzerland. J. Geophys. Res., 115(F3), F03010 (doi: 10.1029/2009JF001509)

Sugiyama S and 7 others (2011) Ice speed of a calving glacier modulated by small fluctuations in basal water pressure. Nature Geosci., 4(9), 597-600 (doi: 10.1038/ngeo1218)

Sugiyama S, Sakakibara D, Matsuno S, Yamaguchi S, Matoba S and Aoki T (2014) Initial field observations on Qaanaaq ice cap, northwestern Greenland. Ann. Glaciol., 55(66), 25-33 (doi: 10.3189/2014AoG66A102)

Thomas RH and 8 others (2000) Substantial thinning of a major east Greenland outlet glacier. Geophys. Res. Lett., 27(9), 1291-1294 (doi: 10.1029/1999GL008473)

Thomas R, Frederick E, Krabill W, Manizade S and Martin C (2009) Recent changes on Greenland outlet glaciers. J. Glaciol., 55(189), 147-162 (doi: 10.3189/002214309788608958)

Van der Veen CJ (1996) Tidewater calving. J. Glaciol., 42(141), 375-385

Van der Veen CJ (1998) Fracture mechanics approach to penetration of surface crevasses on glaciers. Cold Reg. Sci. Technol., 27(1), 31-47 (doi: 10.1016/S0165-232X(97)00022-0) 